\title{
Application of the CIRC (Cooperative Integrated Reading and Compotision) Learning Model to Improve Student Learning Outcomes on the Main Material of a Paragraph
}

\section{Erni Kurniawati}

SD Negeri Buniwah 01

ernikurniawati312@gmail.com

\section{Article History}

accepted 01/11/2020

\begin{abstract}
The purpose of this study was to improve students' ability to find the subject matter of a paragraph. This research is a classroom action research (PTK) which is conducted in two cycles, each cycle consisting of planning, implementation, observation, and reflection stages. The subjects of this study were the fifth grade students of SD Negeri Buniwah 01, Sirampog District, Brebes Regency in the academic year 2020/2021, totaling 17 students. Data collection techniques using observation and tests. Data analysis includes data reduction, data presentation, and drawing conclusions. Research shows that the application of the CIRC (Cooperative Integrated Reading And Composition) learning model can improve learning outcomes in finding the main thoughts of a paragraph in grade V SD Negeri Buniwah 01 in the 2020/2021 academic year as evidenced by the percentage of completeness of learning outcomes in cycle I of $64,7 \%$ to $88.2 \%$ in cycle II.
\end{abstract}

Keywords: CIRC Model, Principal, Student.

\begin{abstract}
Abstrak
Tujuan penelitian ini adalah meningkatkan kemampuan siswa pada materi menemukan pokok pikiran sebuah paragraf. Penelitian ini merupakan penelitian tindakan kelas (PTK) yang dilaksanakan dalam dua siklus, setiap siklus terdiri dari tahap perencanaan, pelaksanaan, observasi, dan refleksi. Subjek penelitian ini adalah siswa kelas V SD Negeri Buniwah 01 Kecamatan Sirampog Kabupaten Brebes tahun pelajaran 2020/2021 yang berjumlah 17 siswa. Teknis pengumpulan data menggunakan observasi dan tes. Analisis data meliputi reduksi data, penyajian data, dan penarikan kesimpulan. Penelitian menunjukkan bahwa penerapan model pembelajaran CIRC (Cooperative Integrated Reading And Composition) dapat meningkatkan hasil belajar dalam menemukan pokok pikiran sebuah paragraph pada siswa kelas $V \mathrm{SD}$ Negeri Buniwah 01 tahun pelajaran 2020/2021 yang dibuktikan dengan persentase ketuntasan hasil belajar pada siklus I sebesar $64,7 \%$ menjadi $88,2 \%$ pada siklus II.
\end{abstract}

Kata kunci : Model CIRC, Pokok Pikiran, Siswa.

Social, Humanities, and Education Studies (SHEs): Conference Series

p-ISSN 2620-9284

https://jurnal.uns.ac.id/shes

e-ISSN 2620-9292 


\section{PENDAHULUAN}

Proses belajar mengajar yang berkualitas ditentukan oleh guru sendiri. Guru merupakan salah satu faktor penentu dalam keberhasilan pembelajaran. Oleh karena itu, guru dituntut memiliki kemampuan untuk mengetahui adanya masalah yang berkaitan dengan praktik pembelajaran yang dikelolanya. Dengan mengetahui adanya masalah dalam pembelajaran, guru diharapkan dapat memperbaikinya. Guru merasa bahwa ada sesuatu yang tidak beres di kelasnya. Jika dibiarkan akan berdampak buruk bagi proses dan hasil belajar siswa. Setelah melihat prestasi belajar siswa, kemudian guru merefleksikan diri dan akhirnya mengidentifikasi masalah dalam proses belajar. Dalam proses pembelajaran Bahasa Indonesia kelas $\mathrm{V}$, peneliti menemukan beberapa masalah yang menyangkut tingkat pemahaman siswa sangat rendah.

Kondisi awal siswa kelas V SD Negeri Buniwah 01 sebelum diadakan penelitian mereka sudah dapat melakukan aktivitas membaca, akan tetapi mereka belum mampu menemukan pokok pikiran dari paragraf yang dibacanya. Hal ini terbukti berdasarkan nilai evaluasi mata pelajaran Bahasa Indonesia sebelum diadakan penelitian masih rendah dan belum memenuhi KKM yang telah ditetapkan.

Bukti menunjukan bahwa siswa kelas V SD negeri Buniwah 01 pada mata pelajaran Bahasa Indonesia materi menemukan pokok pikiran sebuah paragraf, hasil tes studi awal yang dilaksanakan pada tanggal 12 Oktober 2020 diperoleh data dari 17 siswa, baru 8 siswa atau $47 \%$ yang mencapai ketuntasan belajar, sedangkan yang belum tuntas belajar sebanyak 9 siswa atau 53\% dan rata-rata kelas 54,18 dengan KKM 68.

Fenomena di atas menunjukkan pembelajaran belum berhasil secara optimal. Untuk itu, penulis mengidentifikasi sebab-sebab ketidakberhasilan penulis dalam pembelajaran yang diantaranya adalah sebelum diadakan penelitian, guru dalam proses pembelajaran di kelas menggunakan model pembelajaran yang masih konvensional yang banyak didominasi dengan ceramah, sehingga pembelajaran menimbulkan kesan yang kurang menarik bagi siswa dan membuat siswa kurang semangat dan minat dalam belajar di kelas. Dari permasalahan yang muncul dapat disimpulkan bahwa penyebab timbulnya kemampuan menemukan pokok pikiran suatu paragraf yang rendah adalah disebabkan belum adanya model pembelajaran yang dilakukan oleh guru untuk menarik partisipasi dan minat belajar siswa.

Untuk itu, penulis akan menyelesaikan masalah tersebut melalui Penelitian Tindakan Kelas (PTK) dengan alternative pada penerapan model pembelajaran CIRC (Cooperative Integrated Reading and Compotision) untuk meningkatkan hasil belajar dalam menemukan pokok pikiran utama sebuah paragraf pada siswa kelas V SD Negeri Buniwah 01.

\section{METODE}

Penelitian ini merupakan penelitian tindakan kelas (PTK) yang dilaksanakan dalam dua siklus, setiap siklus terdiri dari tahap perencanaan, pelaksanaan, observasi, dan refleksi. Subjek penelitian ini adalah siswa kelas V SD Negeri Buniwah 01 tahun pelajaran 2020/2021 yang berjumlah 17 siswa. Data yang dianalisis berupa data kualitatif yaitu penggunaan model pembelajaran CIRC (Cooperative Integrated Reading and Compotision)dan data kuantitatif yaitu hasil belajar siswa dalam kemampuan menemukan pokok pikiran sebuah paragraph. Teknik pengumpulan data menggunakan observasi dan tes. Uji validitas data menggunakan triangulasi teknik dan triangulasi sumber. Analisis data meliputi reduksi data, penyajian data, dan penarikan kesimpulan. 
PEMBAHASAN

Berdasarkan analisis hasil penelitian yang telah diuraikan maka pembahasan pada penelitian ini sebagai berikut.

1. Penerapan Model Pembelajaran CIRC (Cooperative Integrated Reading and Compotision)

Hasil penelitian menunjukkan peningkatan penerapan model pembelajaran CIRC (Cooperative Integrated Reading and Compotision)yang dilakukan oleh guru. Terlihat pada tabel berikut.

Tabel 1. Peningkatan Penerapan Model Pembelajaran CIRC (Cooperative Integrated Reading and Compotision)

\begin{tabular}{lcc}
\hline \multicolumn{1}{c}{ Langkah } & Siklus I & Siklus II \\
\hline $\begin{array}{l}\text { Membentuk kelompok yang anggotanya 4 orang siswa secara } \\
\text { heterogen }\end{array}$ & 4 & 4 \\
$\begin{array}{l}\text { Guru memberikan wacana sesuai dengan topik pembelajaran } \\
\text { Siswa bekerja sama saling membacakan dan menemukan }\end{array}$ & 3 & 4 \\
$\begin{array}{l}\text { pokok pikiran dan memberi tanggapan terhadap wacana dan } \\
\text { ditulis pada lembar kertas }\end{array}$ & & 3 \\
Mempresentasikan / membacakan hasil kelompok & 3 & \\
Guru dan siswa membuat kesimpulan bersama & 4 & 4 \\
Rata-rata & $\mathbf{3 , 2}$ & $\mathbf{3 , 8}$ \\
Prosentase ketuntasan (\%) & $\mathbf{8 0}$ & $\mathbf{9 5}$ \\
\hline
\end{tabular}

Penerapan model pembelajaran CIRC (Cooperative Integrated Reading and Compotision)dalam pembelajaran Bahasa Indonesia meliputi langkah-langkah : (1) Pembelajaran dimulai dengan membentuk kelompok yang anggotanya 4 orang siswa secara heterogen. (2) Guru memberikan wacana sesuai dengan topik pembelajaran. (3) Siswa bekerja sama saling membacakan dan menemukan pokok pikiran dan memberi tanggapan terhadap wacana dan ditulis pada lembar kertas. (4) Mempresentasikan / membacakan hasil kelompok. (5) Guru dan siswa membuat kesimpulan bersama.

2. Hasil Belajar pada Materi Pokok Pikiran Sebuah Paragraf

Hasil penelitian menunjukkan peningkatan hasil belajar pada materi pokok pikiran sebuah paragraph. Terlihat pada tabel berikut.

Tabel 2. Peningkatan Hasil Belajar

\begin{tabular}{ccccc}
\hline Nilai & F & Siklus I & f & Siklus II \\
& 1 & 5,8 & 6 & $\%$ \\
\hline 100 & 2 & 11,7 & 1 & 35,3 \\
90 & 4 & 23,5 & 4 & 5,8 \\
80 & 4 & 23,5 & 4 & 23,5 \\
70 & 0 & 0 & 0 & 23,5 \\
60 & 1 & 5,8 & 1 & 0 \\
50 & 0 & 0 & 0 & 5,8 \\
40 & 2 & 11,7 & 1 & 0 \\
30 & 3 & 17,6 & 0 & 0 \\
20 & $\mathbf{1 7}$ & $\mathbf{1 0 0}$ & $\mathbf{1 7}$ & $\mathbf{1 0 0}$ \\
Jumlah & $\mathbf{6 7 , 0 5}$ & - & $\mathbf{8 0 , 5 9}$ & - \\
Rata-rata & $\mathbf{1 1}$ & $\mathbf{6 4 , 7}$ & $\mathbf{1 5}$ & $\mathbf{8 8 , 2}$ \\
Tuntas & & & & \\
\hline
\end{tabular}


Peningkatan hasil belajar siswa pada materi menemukan pokok pikiran sebuah paragraph dikur dengan menggunakan pertemuan setelah dilakukan proses pembelajaran. Aspek yang diukur adalah aspek kognitif atau pengetahuan. Berdasarkan hasil evaluasi setelah mengikuti pembelajaran dengan penggunaan model pembelajaran CIRC (Cooperative Integrated Reading and Compotision) pada materi menemukan pokok pikiran sebuah paragraph.

Penggunaan model pembelajaran CIRC (Cooperative Integrated Reading and Compotision)dalam pembelajaran Bahasa Indonesia dapat meningkatkan hasil belajar siswa di kelas V SD Negeri Buniwah 01 secara signifikan. Pada hasil penilaian sebelumnya terdapat 9 siswa dari 17 siswa yang belum mencapai KKM dengan prosentase ketuntasan hasil belajar hanya $47 \%$. Setelah dilakukan tindakan, prosentase ketuntasan hasil belajar pada siklus I meningkat menjadi $64,7 \%$. Pada siklus II terjadi peningkatan kembali menjadi $88,2 \%$. Pada siklus I belum mencapai indicator kinerja penelitian yang ditetapkan. Pada siklus II, ketuntasan hasil belajar siswa telah mencapai 88,2\% dengan KKM 68 sehingga pelaksanaan tindakan dapat dihentikan.

Berdasarkan analisis hasil belajar siswa setelah pelaksanaan tindakan, dapat diambil kesimpulan bahwa penggunaan model pembelajaran CIRC (Cooperative Integrated Reading and Compotision)dapat meningkatkan hasil belajar siswa pada materi menemukan pokok pikiran sebuah paragraph. Hasil penelitian ini juga memperkuat pendapat Saifulloh (2013) bahwa model pembelajaran CIRC dapat membangkitkan motivasi belajar, memperluas wawasan, dan aspirasi guru dalam mengajar. .

\section{SIMPULAN}

Berdasarkan hasil penelitian dan uraian pembahasan, maka dapat diambil simpulan yaitu penggunaan model pembelajaran CIRC (Cooperative Integrated Reading and Compotision)untuk meningkatkan hasil belajar siswa pada materi menemukan pokok pikiran sebuah paragraph kelas V SD Negeri Buniwah 01 Tahun Pelajaran 2020/2021 dilaksanakan dengan langkah-langkah (1) Pembelajaran dimulai dengan membentuk kelompok yang anggotanya 4 orang siswa secara heterogen. (2) Guru memberikan wacana sesuai dengan topik pembelajaran. (3) Siswa bekerja sama saling membacakan dan menemukan pokok pikiran dan memberi tanggapan terhadap wacana dan ditulis pada lembar kertas. (4) Mempresentasikan / membacakan hasil kelompok. (5) Guru dan siswa membuat kesimpulan bersama.

Penggunaan model pembelajaran CIRC (Cooperative Integrated Reading and Compotision) dapat meningkatkan hasil belajar Bahasa Indonesia pada materi menemukan pokok pikiran sebuah paragraph di kelas V SD Negeri Buniwah 01 tahun pelajaran 2020/2021 yang dibuktikan dengan rata-rata ketuntasan hasil belajar siswa pada siklus I sebesar $64,7 \%$ dan meningkat menjadi $88,2 \%$ pada siklus II.

\section{DAFTAR PUSTAKA}

Arikunto,Suharsimi dkk. 2006. Penelitian Tindakan Kelas. Jakarta : PT.Bumi Aksara Arikunto, Suharsimi. 2009. Dasar-Dasar Evaluasi Pendidikan. Jakarta : PT.Bumi Aksara.

Huda, Miftahul. 2011. Cooperative Learning : Metode, Teknik, Struktur dan Model Penerapan. Yogyakarta : Pustaka Pelajar

Muslich, Masnur. 2009. Melaksanakan PTK itu Mudah (Classroom Action Research).Jakarta : Bumi Aksara.

Kusumah, Wijaya dan Dedi Dwitagama. 2010. Mengenal Penelitian tindakan Kelas. Jakarta : PT.Indeks.

Pamungkas, Sri. 2012. Bahasa Indonesia dalam Berbagai Perspektif Dilengkapi dengan Teori, Aplikasi dan Analisis Penggunaan Bahasa Indonesia Saat Ini. Yogyakarta : Penerbit ANDI. 
Rubiyanto, Rubino. 2011. Metode Penelitian Pendidikan. Surakarta : FKIP UMS. Rohmadi, Muhammad dan Yakub Nasucha. 2010. Paragraf : Pengembangan \& Implementasi. Yogyakarta : Media Perkasa.

Tarigan, Henry Guntur. 1994. Menyimak : Sebagai Suatu Keterampilan Berbahasa. Bandung : Angkasa.

Samino dan Saring Marsudi. 2012. Layanan Bimbingan Belajar. Surakarta: Fairuz.

Nafati, Puji Tri.2013. Teknik Pengumpulan Data dalam PTK.http://threenafathy.blogspot.com/2013/05/teknik-pengumpulan-data- dalamptk 9.html (diakses pada Selasa, 5 November 2013 pukul 14.32)

Prayugo,Agus. 2013. Analisis Data dalam PTK.http://agusprayugo.wordpress.com/2010/07/18/analisis-data-dalam-ptk/ (diakses pada Selasa, 5 November 2013 pukul 11.50)

Syarief,Jenius. 2013. Model Pembelajaran Cooperative Integrated and Reading. (CIRC).http://syariefsimple16.blogspot.com/2013/01/model-pembelajaran cooperative.html (diakses pada Senin, 28 november 2013 pukul 10.02) 